University of Nebraska - Lincoln

DigitalCommons@University of Nebraska - Lincoln

1990

\title{
The role of sediment type in growth and fecundity of mud snails (Hydrobiidae)
}

Valery E. Forbes

University of Nebraska-Lincoln, veforbes@umn.edu

Glenn R. Lopez

State University of New York, Stony Brook, glenn.lopez@stonybrook.edu

Follow this and additional works at: https://digitalcommons.unl.edu/biosciforbes

Forbes, Valery E. and Lopez, Glenn R., "The role of sediment type in growth and fecundity of mud snails (Hydrobiidae)" (1990). Valery Forbes Publications. 53.

https://digitalcommons.unl.edu/biosciforbes/53

This Article is brought to you for free and open access by the Papers in the Biological Sciences at DigitalCommons@University of Nebraska - Lincoln. It has been accepted for inclusion in Valery Forbes Publications by an authorized administrator of DigitalCommons@University of Nebraska - Lincoln. 


\title{
The role of sediment type in growth and fecundity of mud snails (Hydrobiidae)
}

\author{
Valery E. Forbes and Glenn R. Lopez \\ Marine Sciences Research Center, State University of New York, Stony Brook, NY I I 794, USA \\ Corresponding author - V. E. Forbes
}

\begin{abstract}
We test the hypothesis that body size and population density of the deposit-feeding gastropod, Hydrobia truncata, are greater in muddy than in sandy habitats as a result of faster growth on fine- compared to coarse-grained sediments. We refute this hypothesis using a combination of field measurements and laboratory experiments. Three out of three populations tested had higher maximal growth rates and two of three popu-lations approached their asymptotic size more quickly on sand than on silt-clay fractions of natural sediment. Growth decreased with increasing snail density and was as high or higher on sand as on silt-clay at all densities. Two populations were more fecund on sand than on silt-clay, and fecundity of the third population was not affected by sediment type. We show that the smaller body sizes observed in snails from the sandiest habitat result from late recruitment of these snails, relative to the other populations.
\end{abstract}

Keywords: Deposit feeder, Population dynamics, Intraspecific variation

$$
\diamond \diamond \diamond \diamond \diamond \diamond \diamond
$$

Sediment grade has been considered of primary importance in controlling the distribution and abundance of deposit feeder populations. Deposit feeders are generally most numerous in fine-grained, organic-rich sediment (Sanders 1958; Newell 1965). Conditions that result in the deposition of small sediment particles tend to enhance the accumulation of low-density organic material (Mayer et al. 1985). Furthermore, the high surfaceto-volume ratio of small particles provides relatively more area for the attachment of microbes and organic coatings (Zobell 1938; Newell 1965; Yamamoto and Lopez 1985; but see Cammen 1982; Whitlatch and Weinberg 1982; DeFlaun and Mayer 1983). Since deposit feeders utilize some combination of organic detrital ma- terial and living microbes for food, it has been widely held that sediment particle size limits food availability for populations of deposit feeders (Lopez and Levinton 1987, for review). Correlations between deposit feeder abundance and various measures related to sedimentary food value and results of direct density manipulations provide convincing evidence that populations of deposit feeders are often food-limited (Newell 1965; Longbottom 1970; Levinton 1972, 1977; Fenchel and Kofoed 1976; Levinton and Bianchi 1981; Bianchi and Levinton 1984; Olafsson 1986).

Body size and population density of hydrobiid gastropods have been positively correlated with silt-clay content of the sediment (Newell 1965; Chatfield 1972; Fish and Fish 1974). The larger body sizes observed have been hypothesized to be the result of faster growth on muddy sediments (Fish and Fish 1974). Our purpose was to test the hypothesis that larger body sizes and densities of Hydrobia truncata populations from Long Island Sound (NY, USA) occur in muddy relative to sandy habitats as a result of faster growth on fine- compared to coarse-grained sediments. We combined field measurements of body size and population density with laboratory estimates of growth, mortality, and fecundity in order to determine the role of sediment type in controlling field distributions of this species.

\section{Materials and methods}

\section{Habitat characteristics}

The locations of the three study sites are shown in Figure 1. Flax Pond, a Spartina salt marsh, is a protected, low energy, intertidal habitat. The sediment is poorly sorted, and modal particle size is $125-250 \mu \mathrm{m}$. The sediment consists of approximately $12 \%$ silt-clay and has a total organic content of $2.7 \%$ by weight (Forbes 1988). 


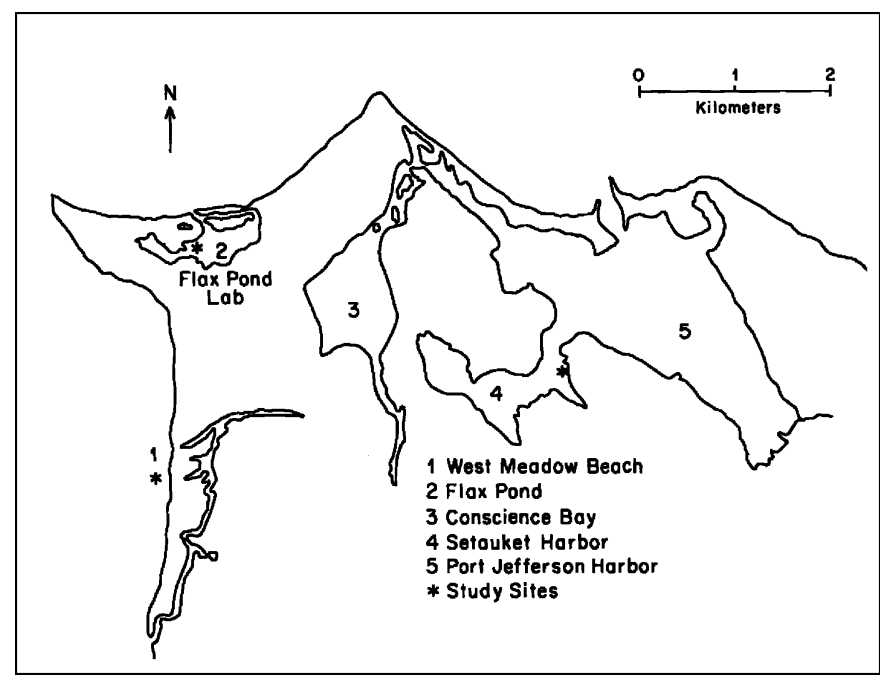

Figure I. Map of the study sites

The Setauket Harbor site is a moderately protected, intertidal-sand flat. The sediment is poorly sorted, and the percentage of fine particles increases away from shore. Modal particle size is $125-250 \mu \mathrm{m}$ with $2 \%$ silt-clay and an organic content of $1.4 \%$ (Forbes 1988).

West Meadow Beach is the most exposed of the three intertidal habitats. It is open to Long Island Sound and is subject to frequent sediment transport events, particularly during the winter months. Modal particle size is $297-420 \mu \mathrm{m}$; there are no particles $<125 \mu \mathrm{m}$. Total organic content is approximately $0.5 \%$ by weight (Forbes 1988).

The temperature of surface sediment and overlying water was measured weekly at low tide to the nearest $0.5^{\circ} \mathrm{C}$. There was no consistent difference in sediment or water temperature among sites. Temperatures were highest during July and August and lowest in February. Salinity was similar at the three sites and generally varied between $25-30 \%$ (Forbes 1988).

\section{Field measurements}

Sedimentary food content was estimated by chlorophyll- $\alpha$ concentration since benthic microalgae are the most important food source for Hydrobia species (Fenchel et al. 1975; Kofoed 1975; Fenchel and Kofoed 1976; Jensen and Siegismund 1980; Levinton and Bianchi 1981; Bianchi and Levinton 1984). Chlorophyll- $\alpha$ concentration $(\mu \mathrm{g} / \mathrm{mg}$ sediment dry weight) was estimated by fluorometric analysis (Turner Designs Fluorometer) following extraction with $90 \%$ acetone for $15-20 \mathrm{~h}$, and was corrected for phaeopigment (Strickland and Parsons 1972).

Seasonal variation in snail density was estimated by taking three $\left(5 \mathrm{~cm}\right.$ depth $\left.\times 34.5 \mathrm{~cm}^{2}\right)$ cores at each site. Cores were sieved to $500 \mu \mathrm{m}$ and sorted under a dissecting microscope immediately upon return to the laboratory, and the total number of live snails was counted.

To obtain estimates of body size, snails were collected weekly at each site from July 1985 through July 1987 by filling a 1 L container with (unsieved) surface sediment. Shell lengths of the first one hundred snails encountered were measured under a dissecting microscope to obtain a mean for each site. In several of the samples collected during the winter at West Meadow Beach, fewer than 100 snails were obtained. Therefore for these samples mean shell lengths were based on fewer individuals. Measurements of shell length were made at $12 \times$ (for snails $\geq 2 \mathrm{~mm}$ ) or $20 \times$ (for snails $<2 \mathrm{~mm}$ ) with an ocular micrometer, to the nearest 0.04 $\mathrm{mm}$ or $0.025 \mathrm{~mm}$ respectively.

\section{Laboratory growth experiment I}

This experiment was designed to investigate the effect of sediment type on growth rate. Snails from Flax Pond, Setauket Harbor and West Meadow Beach populations were grown individually in $35 \mathrm{~mm}$ diameter polystyrene culture dishes $\left(0.10\right.$ snails $\left./ \mathrm{cm}^{2}\right)$ for 11 months, beginning in July, 1985. The cultures were kept at room temperature (approximately $21^{\circ} \mathrm{C}$ ). No attempt was made to regulate light conditions; however, fresh sediment (ca. 3.5 gm dry weight) and seawater (ca. $5 \mathrm{~mL}$ ) were replaced weekly. Seawater $(28 \%$ ) used in all laboratory experiments was glass fiber filtered. The $<63 \mu \mathrm{m}$ fraction of sediment from Flax Pond and the 300-600 $\mu \mathrm{m}$ fraction of sediment from West Meadow Beach comprised the two sediment treatments used in all growth and fecundity experiments. The fractions were chosen from separate sites so that the natural diatom assemblages associated with each sediment type would be represented. Each week, snails were blotted dry and weighed on a Cahn (model 26) electrobalance. Blotted weight is an excellent indicator of shell dimensions (Levinton and Bianchi 1981) and is correlated with dry tissue weight $\left(\log _{10}(\right.$ dry wt $)=1.465+2.3421 \log _{10}$ (shell length); $\mathrm{N}=1124 ; \mathrm{r}=0.93$; Forbes, unpublished). Twelve replicates were used for each combination of sediment type and population ( 2 sediment types $\times 3$ populations).

Specific growth rates (SGR) were calculated as

$$
\mathrm{SGR}=\left(\log _{\mathrm{e}} \mathrm{W}_{2}-\log _{\mathrm{e}} \mathrm{W}_{1}\right) / \mathrm{t}
$$

where $W_{1}$ and $W_{2}$ are weights at times $t_{1}$ and $t_{2}$ respectively, and $t$ is in days (Kaufmann 1981). SGR was plotted against geometric mean size, $W=\left(W_{2} \times W_{1}\right)^{1 / 2}$, and the data were fitted to several standard growth curves. Standard least squares regression was used to obtain the parameters of the model equation. The Gompertz curve, in which SGR $=b-a \operatorname{Ln}(W)$, gave the highest correlation coefficient in 4 of 6 cases, as well as in field growth estimates for this species (Forbes, unpublished) and was therefore used in all further growth analyses. The parameter ' $b$ ' is the maximum growth rate; ' $a$ ' is a measure of the growth schedule or rate at which an animal approaches its asymptotic size (i.e., the rate of change of the size specific growth rate with increasing size). Residual analysis was used to detect outliers and points with high leverage. Any point that fit both of these criteria was deleted from the analysis (Sokal and Rohlf 1981). A maximum of 7 out of 139 points in a single regression was deleted using these criteria. Average shell lengths were calculated from a regression against blotted wet weight to facilitate comparison with field data.

\section{Laboratory growth experiment II}

In this experiment we examined the combined effects of sediment type and snail density on growth rate of H. truncata. Snails were cultured for 31 days (September 7 to October 9, 1987) at three densities: 0.10, 1.04, and 2.10 snails $/ \mathrm{cm}^{2}$ for Flax Pond and Setauket Harbor populations, and 0.10, 1.04, and 3.10 snails $/ \mathrm{cm}^{2}$ for the West Meadow Beach population. There were two replicates for each combination of population, sediment type, and density (with the exception of the high density West Meadow groups which were not replicated due to difficulty in obtaining enough animals) giving a total of 34 groups ( 2 sediment types $\times 3$ density levels $\times 3$ populations)

The snails were maintained in $35 \mathrm{~mm}$ diameter polystyrene culture dishes $\left(1,10\right.$, and 20 (or 30) snails/dish) at $17^{\circ} \mathrm{C}$. Seawater (ca. $5 \mathrm{~mL}$ ) and $2.5 \mathrm{~mL}$ sediment slurry (ca. $3.5 \mathrm{gm}$ dry weight) were added to each dish. Seawater was changed weekly; sediment was not changed, but the cultures were maintained on a 14L:10D light cycle to permit microalgal growth. At the beginning and end of the experiment, the snails in each dish were blotted dry and weighed to the nearest $0.001 \mathrm{mg}$. Growth rate $(\mathrm{mg} / \mathrm{snail})$ was calculated as an average based on the weight gain of the entire group. At the conclusion of the experiment, sediment chlorophyll- $\alpha$ concentrations were measured by fluorometry as described above. 


\section{Laboratory fecundity experiment}

This experiment determined the effects of sediment type on the number of eggs laid and percent hatch. Adult snails were collected at the onset of egg production in the field. Since the West Meadow Beach population recruited approximately 1.5 months later than the other populations, fecundity estimates for this population commenced at a later time (July 2, 1987), but under identical laboratory conditions, as for the other groups (April 17, 1987). One female was placed in each of 72 culture dishes $(35 \mathrm{~mm}$ diameter). A male was added to each dish to ensure fertilization. Seawater (changed weekly) and $2.5 \mathrm{~mL}$ sediment slurry (ca. $3.5 \mathrm{gm}$ ) were added to each culture. Twelve replicates were used in each combination of sediment type and population ( 2 sediment types $\times 3$ populations). The cultures were maintained at $17{ }^{\circ} \mathrm{C}$ under a 14L:10D light cycle to permit microalgal growth. Shell lengths of the adults were measured prior to and following the experiment. Cultures were examined microscopically every other day for the presence of newly hatched juveniles. Once eggs began to hatch, juveniles were removed from the sediment and preserved in $70 \%$ ethanol and stained with Rose Bengal. The experiment was terminated 18 days after the first eggs hatched. By this time the rate of hatching had slowed considerably. At the conclusion of the experiment, the sediments containing unhatched eggs were preserved and all juveniles and eggs counted.

Statistical analyses of field and laboratory data, detailed in the results, were performed using SYSTAT (Wilkinson 1986).

\section{Results}

\section{Field measurements}

With the exception of the August sampling date, chlorophyll- $\alpha$ values were consistently lower at West Meadow Beach than at either of the other two sites (Table 1). On three of six sampling dates (Mar, May, Aug), chlorophyll- $\alpha$ values were higher at Setauket Harbor than Flax Pond, on two dates (Sept., Feb.) Flax Pond values were higher, and on the remaining date (June), there was no difference between the two sites. Average values were: 0.043 $\mu \mathrm{g} / \mathrm{mg}$ for Flax Pond; $0.052 \mu \mathrm{g} / \mathrm{mg}$ for Setauket Harbor; $0.011 \mu \mathrm{g} / \mathrm{mg}$ for West Meadow Beach.
Snail densities at West Meadow Beach were generally lower than at the other two sites (Table 1). In March, May, August, and February, densities were lower at West Meadow Beach than at Flax Pond; in March, June, August, September and February, West Meadow Beach densities were lower than those at Setauket Harbor. In March and May densities were lower at Setauket Harbor than at Flax Pond. In June and September, densities were lower at Flax Pond than at Setauket Harbor. On the remaining dates, there were no significant differences in density among sites. Average snail densities at each site were 2.98 snails $/ \mathrm{cm}^{2}$ for Flax Pond, 4.55 snails $/ \mathrm{cm}^{2}$ for Setauket Harbor, and 0.54 snails/ $\mathrm{cm}^{2}$ for West Meadow Beach. Low densities following recruitment (June for Flax Pond and Setauket Harbor; August for West Meadow Beach) were due to newly hatched juveniles passing through the $500 \mu \mathrm{m}$ collection sieve. The new recruits first appeared in the August collection at Flax Pond and Setauket Harbor and in the September collection at West Meadow Beach.

Average shell lengths of the 1986 cohort of snails from each habitat are shown in Figure 2. (Similar curves were obtained for the 1985 year class (Forbes 1988)). Snails from West Meadow Beach were smaller than Flax Pond and Setauket Harbor snails throughout the year. Flax Pond and Setauket Harbor populations were indistinguishable in size for the first 3 months following recruitment. After this time, the average size of Flax Pond snails was approximately $0.2 \mathrm{~mm}$ greater than Setauket Harbor snails.

For Flax Pond and Setauket Harbor populations, the most rapid increase in length occurred during the first three months following recruitment (June, July, and August). By September, these populations reached sexual maturity (determined by whorl number and egg laying behavior when brought into the laboratory) and showed little additional growth. At West Meadow Beach, recruitment occurred 1.5 months later than at the other sites and was followed by approximately 7 weeks of rapid growth. Average body size changed very little over the fall and winter months for

Table I. Field Measurements. Microalgal concentration of field sediments ( $\mu \mathrm{g} \mathrm{chl}-\alpha /(\mathrm{mg}$ dry wt sed)) and densities of H. truncata (snails $/ \mathrm{cm}^{2}$ ); Mean (SD, N). Data were log transformed to reduce heterogeneity of variances prior to ANOVA. Separate ANOVA's (and planned comparisons among means, Sokal and Rohlf, I 98I) for population effect on chlorophyll- $\alpha$ and snail density were calculated for each date; all were significant at $P<0.0$ I. Solid lines join means that were not significantly different $(P>0.05)$

\begin{tabular}{|c|c|c|c|c|c|c|c|}
\hline \multirow{2}{*}{$\frac{\text { Date }}{\text { Mar } 87}$} & \multirow[b]{2}{*}{ Chl- $\alpha$} & \multicolumn{2}{|c|}{ Flax Pond } & \multicolumn{2}{|c|}{ Setauket Harbor } & \multicolumn{2}{|c|}{ W. Meadow Beach } \\
\hline & & 0.036 & $(0.0012,4)$ & 0.057 & $(0.0017,4)$ & 0.008 & $(0.0025,4)$ \\
\hline & Density & 2.95 & $(0.349,3)$ & 0.73 & $(0.622,3)$ & 0.00 & $(0.000,3)$ \\
\hline \multirow[t]{2}{*}{ May 87} & Chl- $\alpha$ & 0.038 & $(0.002 I, 4)$ & 0.068 & $(0.0066,4)$ & 0.016 & $(0.0006,4)$ \\
\hline & Density & 2.21 & $(0.972,3)$ & $\underline{0.76}$ & $(0.644,3)$ & $\underline{0.03}$ & $(0.050,3)$ \\
\hline \multirow[t]{2}{*}{ Jun 87} & Chl- $\alpha \alpha$ & $\underline{0.071}$ & $(0.0107,4)$ & $\underline{0.074}$ & $(0.0021,4)$ & 0.007 & $(0.0002,4)$ \\
\hline & Density & $\underline{0.59}$ & $(0.453,3)$ & 3.94 & $(1.809,3)$ & $\underline{0.07}$ & $(0.017,3)$ \\
\hline \multirow[t]{2}{*}{ Aug 87} & Chl- $\alpha$ & $\underline{0.015}$ & $(0.0065,4)$ & 0.036 & $(0.0026,4)$ & $\underline{0.015}$ & $(0.0006,4)$ \\
\hline & Density & 6.68 & $(4.260,3)$ & 11.61 & $(3.880 .3)$ & 0.44 & $(0.608,3)$ \\
\hline \multirow[t]{2}{*}{ Sep 87} & Chl- $\alpha$ & 0.047 & $(0.0049,4)$ & 0.037 & $(0.0018,4)$ & 0.007 & $(0.0005,4)$ \\
\hline & Density & 3.42 & $(0.652,3)$ & 5.85 & $(1.336,3)$ & 2.65 & $(0.422,3)$ \\
\hline \multirow[t]{2}{*}{ Feb 88} & Chl- $\alpha$ & 0.052 & $(0.0037,8)$ & 0.037 & $(0.0020,6)$ & 0.012 & $(0.0006,6)$ \\
\hline & Density & 2.03 & $(0.559,3)$ & $\underline{4.42}$ & $(2.795,3)$ & $\underline{0.07}$ & $(0.067,3)$ \\
\hline
\end{tabular}



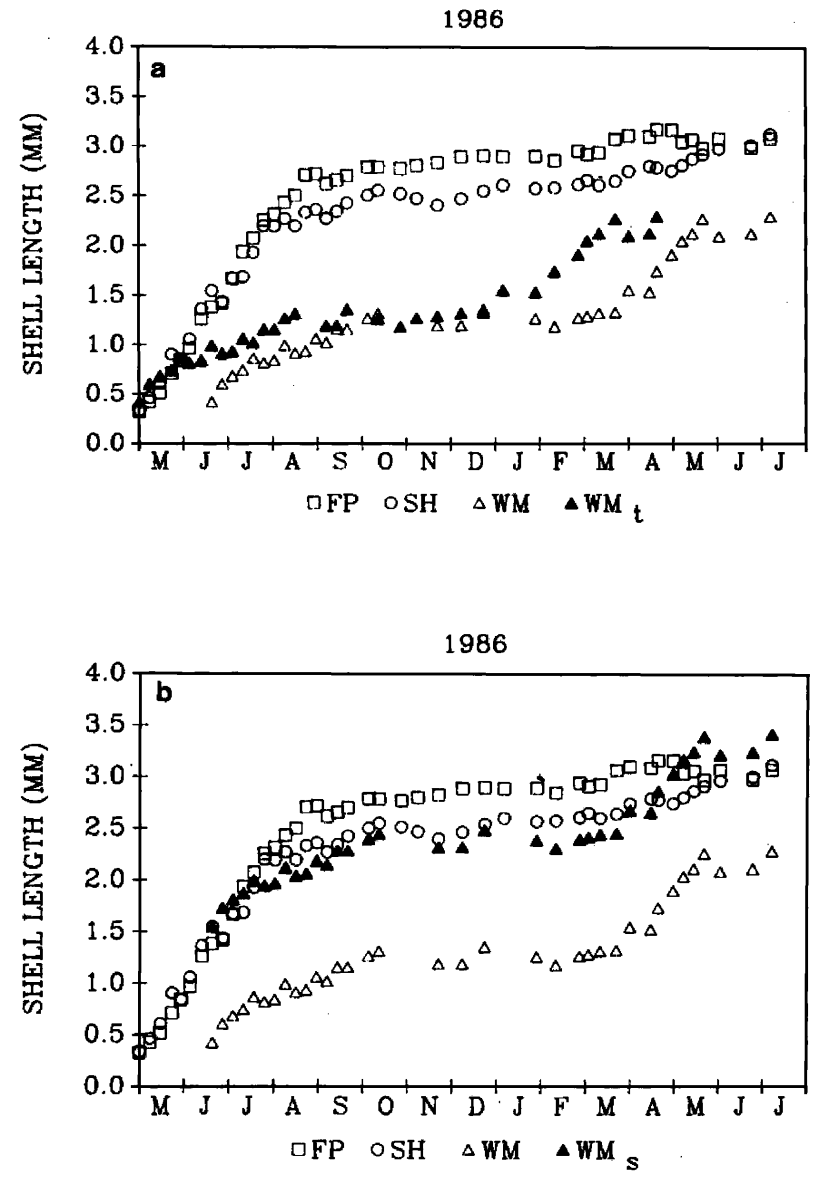

Figure 2. Average shell length of Hydrobia truncata from three populations. FP = Flax Pond, $\mathrm{SH}-=$ Setauket Harbor, $\mathrm{WM}=$ West Meadow Beach. a) $W M_{t}=$ average size of West Meadow Beach snails adjusted for the difference in recruitment timing. b) $W M_{s}=$ average size of West Meadow Beach snails adjusted for the size difference at recruitment.

all populations, but in the spring a second period of rapid growth was observed in the West Meadow Beach population prior to snails reaching sexual maturity. When individuals from West Meadow recruited, in mid-July, the Flax Pond and Setauket Harbor juveniles were approximately 1.5 $\mathrm{mm}$ in length. By adjusting the West Meadow curve for the time difference in recruitment $\left(\mathrm{WM}_{1}\right.$, Figure $\left.2 \mathrm{a}\right)$ we can compare size-specific growth rates among populations. During the first 7 weeks following recruitment, growth rates were similar among the 3 populations. After this period, West Meadow Beach snails appeared to decrease their growth relative to the other populations. In Figure $2 b$, we retain the real time axes but adjust the West Meadow curves for the initial size lag (by addi-tion of the size difference between Setauket Harbor and West Meadow snails at the time of the latter's recruitment; $W_{S}$ ). The similarity in shape of $W M$, to the Flax Pond and Setauket Harbor size curves indicates that environmental constraints on growth outweigh size-specific factors in the West Meadow Beach population and suggests that the smaller size of West Meadow Beach snails occurs primarily as a result of the recruitment time lag interacting with environmental constraints on growth.
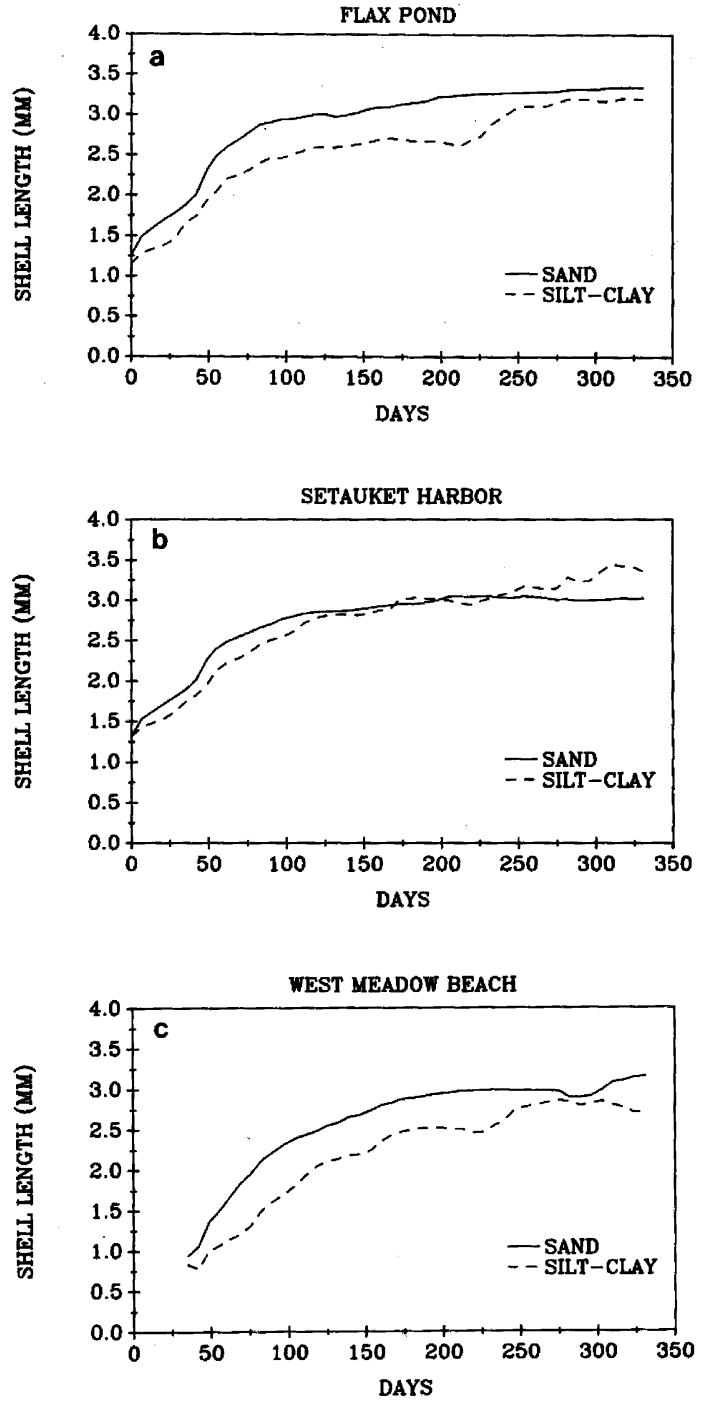

Figure 3. Laboratory Growth Experiment I. Average shell length of a) Flax Pond, b) Setauket Harbor, and c) West Meadow Beach snails as a function of time and sediment type. Shell lengths were calculated from a regression against wet weight to facilitate comparison with field data.

\section{Laboratory growth experiment I}

Average snail size versus time for three populations and two sediment treatments is shown in Figure 3. Specific growth rate regression parameters are provided in Table 2. Growth schedules (i.e., slopes) of individual Flax Pond snails were similar between sediment treatments, however, snails from this population had higher initial growth rates (i.e. yintercepts) on sand compared to silt-clay (Table 3). Setauket Harbor and West Meadow Beach snails approached their asymptotic size more rapidly and had higher initial growth rates on sand than on silt-clay (Table 3 ).

The number of days to reach 50\% mortality was 98 for Flax Pond snails on sand, 154 for Flax Pond snails on siltclay, 283 for Setauket Harbor snails on sand, 255 for Setauket Harbor snails on silt-clay, 261 for West Meadow Beach snails on sand, and 14 for West Meadow Beach snails on silt-clay. 
Table 2. Growth Experiment I. Regression parameters estimated by fitting data to Gompertz growth model (see text for equation). Regression equations for all groups were significant at $p<0.0000 \mathrm{I}$. FP $=$ Flax Pond, $\mathrm{SH}=$ Setauket Harbor, WM $=$ West Meadow Beach, SA $=$ Sand, SC = Silt-Clay

\begin{tabular}{|c|c|c|c|c|c|c|c|}
\hline$\frac{\text { Population }}{\text { FP }}$ & $\begin{array}{l}\text { Sediment } \\
\text { SA }\end{array}$ & \multicolumn{2}{|c|}{ Slope (SE) } & \multicolumn{2}{|c|}{ Y-Intercept (SE) } & $\frac{n}{275}$ & $\begin{array}{l}r \\
0.693\end{array}$ \\
\hline FP & SC & I.I74 & $(0.0984)$ & 1.939 & $(0.1152)$ & 268 & 0.590 \\
\hline $\mathrm{SH}$ & SC & 1.093 & $(0.0776)$ & 2.020 & $(0.1021)$ & 360 & 0.597 \\
\hline WM & SA & 1.477 & $(0.0766)$ & 2.309 & $(0.0852)$ & 387 & 0.701 \\
\hline WM & SC & 1.139 & $(0.1177)$ & 1.534 & $(0.1 I I I)$ & 139 & 0.639 \\
\hline
\end{tabular}

Table 3. Growth Experiment I. Results of ANCOVA of shell length and sediment effects on specific growth rate (calculated using regression equations shown in Table 2) for Flax Pond, Setauket Harbor, and West Meadow Beach populations

\begin{tabular}{|c|c|c|c|c|c|}
\hline \multicolumn{6}{|l|}{ I. Flax Pond } \\
\hline Source & SS & DF & MS & F-Ratio & $P$ \\
\hline Size & 435.35 & I & 435.35 & 374.46 & $<0.001$ \\
\hline Size $\times$ Sed & 3.51 & I & 3.51 & 3.02 & 0.083 \\
\hline Error & 630.16 & 540 & 1.17 & & \\
\hline Size & 594.41 & I & 594.41 & 720.35 & $<0.001$ \\
\hline Sediment & 37.39 & I & 37.39 & 45.31 & $<0.001$ \\
\hline Size $\times$ Sed & 32.66 & I & 32.66 & 39.58 & $<0.001$ \\
\hline Error & 652.71 & 791 & 0.83 & & \\
\hline Sediment & 37.28 & I & 37.28 & 31.35 & $<0.001$ \\
\hline Size $\times$ Sed & 7.06 & I & 7.06 & 5.93 & 0.015 \\
\hline Error & 620.73 & 522 & 1.19 & & \\
\hline
\end{tabular}

\section{Laboratory growth experiment II}

Growth rate in the three populations of Hydrobia truncata decreased with increasing snail density (Figure 4). Sediment type had no effect on growth rate of Flax Pond and Setauket Harbor snails (Table 4). West Meadow Beach snails grew more on sand than on silt-clay at all densities; the difference in growth between sediment fractions was greatest at the lowest snail density (Figure 4c). Sediment chlorophyll- $\alpha$ was not affected by snail density or population, but was much lower on sand than on silt-clay; there was no significant interaction between snail density and sediment type on chlorophyll- $\alpha$ concentration (Table 5).

\section{Laboratory fecundity experiment}

Sediment type had no effect on the number of eggs laid by Flax Pond $H$. truncata or on the percentage of those eggs that hatched over an 18 day period (Figure 5 a, Table 6). Setauket Harbor snails laid more eggs on sand, and a greater percentage of eggs hatched on sand than on silt-clay (Fig- ure 5b, Table 6). Percent hatch on West Meadow Beach snails was not affected by sediment type, but snails from this population laid more eggs on sand (Figure 5c, Table 6). Also, the West Meadow Beach adults grew more on sand so that by the end of the experiment, shell lengths of the adults were significantly greater on sand than on silt-clay $(\mathrm{t}$-statistic $=$ 2.577, $\mathrm{P}=0.017)$.

\section{Discussion}

Given observations of the predominance of deposit feeders in fine-grained, organic-rich sediments (Sanders 1958; Newell 1965) and evidence for food limitation of natural populations of deposit feeders (Levinton 1972, 1977; Fenchel and Kofoed 1976; Levinton and Bianchi 1981; Bianchi and Levinton 1984; Olafsson 1986), we hypothesized that larger body sizes and densities of Hydrobia truncata from muddy habitats in Long Island Sound resulted from faster growth on fine- compared to coarse-grained sediments. Our results clearly refute this hypothesis. 

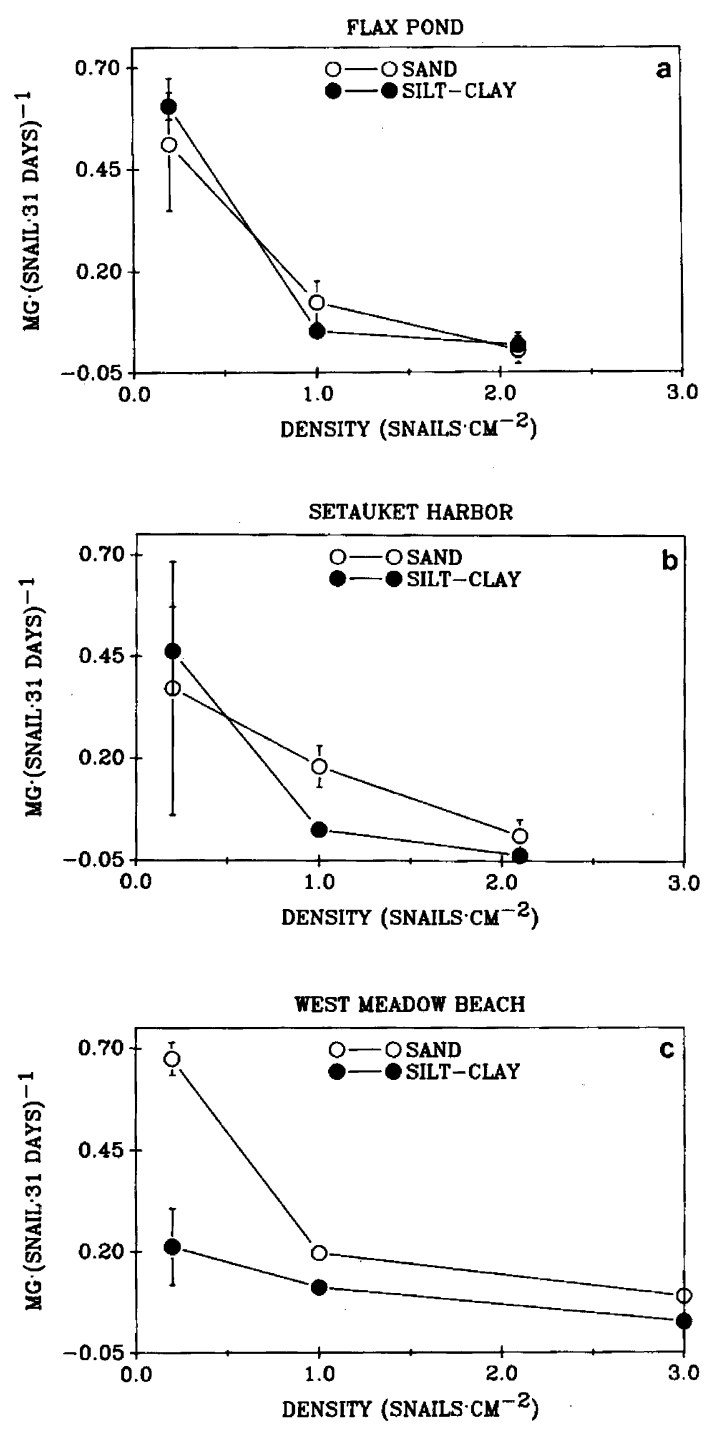

Maximum sizes attained by snails in the field were approximately 3-3.5 for Flax Pond snails, 3.0 for Setauket Harbor snails and 2-2.25 for West Meadow Beach snails. West Meadow Beach snails recruited 1.5 months later than the other populations and reproduced at a smaller size. Differences in maximum size among populations reared in the laboratory were less than in the field. In the laboratory, Flax Pond and Setauket Harbor snails attained a maximum size of 3-3.5 mm; West Meadow Beach snails reached 2.75-3.0 $\mathrm{mm}$. Growth patterns exhibited by laboratory-grown snails were also similar among the three populations (Figure 3). In the field, however, growth rates of West Meadow snails decreased at a smaller body size but at the same time (i.e., early autumn) as the other populations (Figure 2), suggesting that environmental constraints may limit growth during autumn and winter. As a result, West Meadow Beach snails overwintered at a much smaller size than the other populations. Pronounced growth bands, separating pre-from post-winter growth, are present in the majority of West Meadow Beach snails in the spring (Forbes, pers. obs.), suggesting that the second growth spurt observed in field collected-snails is due to growth and not migration. Observations of size at sexual maturity (G. Davis, pers. comm.), as well as egg laying behavior of field-collected animals, suggest that Flax Pond and Setauket Harbor, but not West Meadow Beach, populations reach sexual maturity approximately 3 months following recruitment. The spring growth

Figure 4: a-c. Laboratory Growth Experiment II. Average weight gain of $\mathrm{H}$. truncata from a) Flax Pond, b) Setauket Harbor, and c) West Meadow Beach populations as a function of snail density and sediment particle size. Error bars indicate $95 \%$ confidence limits around the mean.

Table 4. Growth Experiment II. Results of 2-way ANOVA of sediment and density effects on weight gain of $H$. truncata from Flax Pond, Setauket Harbor, and West Meadow Beach populations. Homogeneity of variances was tested using Bartlett's Test; $P>0.05$. The sediment $\times$ density interaction term was omitted from the West Meadow Beach ANOVA due to non-replication of the high density treatment

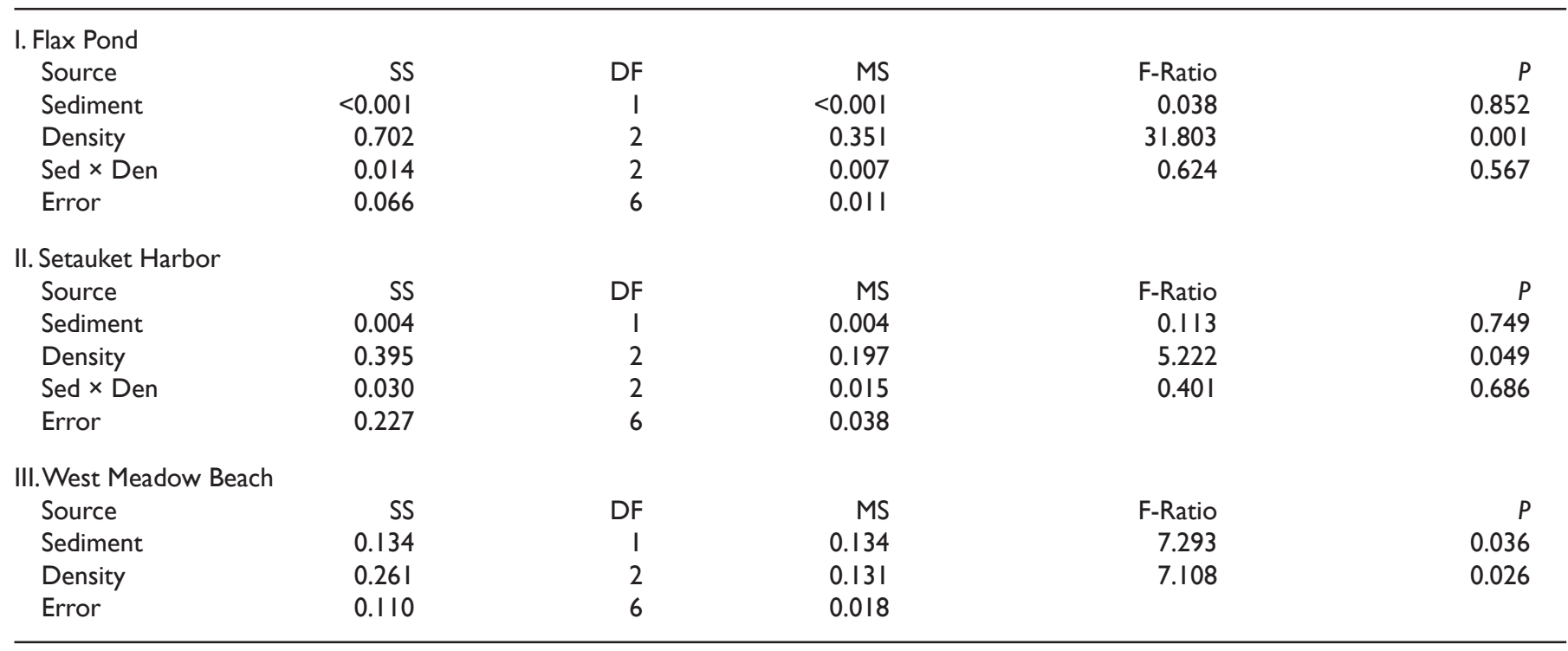


Table 5. Growth Experiment II. Microalgal concentration ( $\mu \mathrm{g} \mathrm{Chl}-\alpha /$ $\mathrm{mg}$ ) of experimental sediments and results of 2-way ANOVA of the effect of sediment type and snail density on Chl- $\alpha$ concentration of experimental sediments. Data are pooled among populations since population had no effect on $\mathrm{Chl}-\alpha$ (based on initial 3-way ANOVA of population, sediment, and density effects). Sediment $x$ density interaction term is omitted since each sediment type had a single control treatment. $*$ = no SE since $\mathrm{n}=\mathrm{I}$ for controls.

\begin{tabular}{|c|c|c|c|c|c|}
\hline & Snail De & sity & Mean & SE & $\mathrm{n}$ \\
\hline \multirow[t]{4}{*}{ Sand } & 0.00 & & 0.0043 & $*$ & (I) \\
\hline & 0.10 & & 0.0044 & $(0.00025)$ & (6) \\
\hline & 1.04 & & 0.0047 & $(0.00054)$ & (6) \\
\hline & 2.10 & & 0.0047 & $(0.0005 \mathrm{I})$ & (5) \\
\hline \multirow[t]{4}{*}{ Silt-Clay } & 0.00 & & 0.161 & $*$ & (I) \\
\hline & 0.10 & & 0.143 & $(0.0130)$ & (6) \\
\hline & 1.04 & & 0.143 & $(0.0075)$ & (6) \\
\hline & 2.10 & & 0.139 & $(0.0046)$ & (5) \\
\hline Source & SS & DF & MS & F-Ratio & $P$ \\
\hline Sediment & 0.1718 & I & 0.17183 & 714.907 & $<0.001$ \\
\hline Density & 0.0002 & 3 & 0.00007 & 0.277 & 0.842 \\
\hline Error & 0.0074 & 31 & 0.00024 & & \\
\hline
\end{tabular}

spurt may be necessary for the West Meadow Beach snails to reach a minimum size for reproduction. The annual, semelparous life history of these populations prevents late reproducing snails from catching up and will act to maintain the lag in recruitment once initiated.

Population density of $H$. truncata was lowest at West Meadow Beach, which had the lowest average sedimentary chlorophyll- $\alpha$ content of the three habitats. Although conditions favoring high standing stocks of benthic microalgae also favor large sizes and densities of Hydrobia truncata, our results indicate that sediment type does not directly control growth and fecundity in field populations. For a given sediment size fraction, growth of Hydrobia species is limited by microalgal standing stock (Levinton and Bianchi 1981; Bianchi and Levinton 1984). Comparisons of food availability between sediment fractions are confounded by the ability of snails to browse particle surfaces. Browsing is an effective technique for food-particle selection and results in greater ingestion rates than expected on the basis of bulk estimates of sediment microalgal concentration (Lopez and Kofoed 1980).

We found no density-dependent reduction in sedimentary microalgal concentration (Table 5), although snail growth was strongly and negatively related to density. There was a trend toward decreasing chlorophyll- $\alpha$ concentration with increasing density on silt-clay, but this trend was not significant. Levinton $(1982 ; 1985)$ and Morrisey (1987; 1988) also found depressed growth with increasing Hydrobia density, however, both authors found that increasing snail density decreased diatom standing stock (estimated by epipfluorescence counts). We suggest several explanations to explain this discrepancy: 1) chlorophyll- $\alpha$ concentration did not adequately reflect food availability (e.g., grazing by snails may select for smaller or less digestible diatom species which might negatively influence growth rate, but not be reflected in bulk estimates of
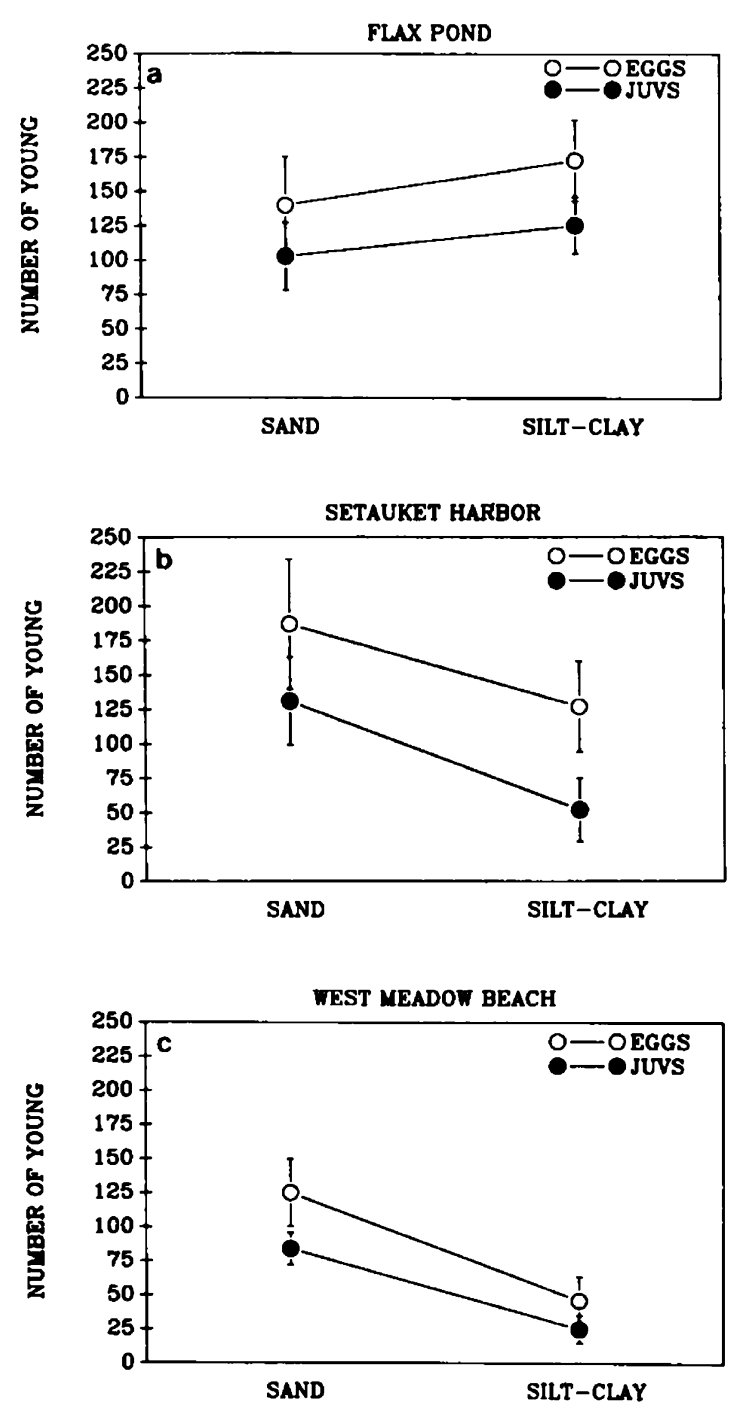

Figure 5: a-c. Laboratory Fecundity Experiment. The effect of sediment particle size on the number of eggs laid and the number of juveniles hatched (\% hatch =juvs/eggs) for $H$. truncata from a) Flax Pond, b) Setauket Harbor, and c) West Meadow Beach populations. Error bars indicate $95 \%$ confidence limits around the mean.

chlorophyll- $\alpha$ (Lopez and Levinton 1978; Kofoed, pers. comm.), 2) reduction in growth in our experiments at high densities was caused by interference competition (Levinton 1985), 3) differences in chlorophyll-a were not statistically discernible due to the small sample size of our data.

The fact that growth rates in laboratory experiments were as high or higher on coarse compared to fine-grained sediments is consistent with carbon absorption and loss estimates (Forbes and Lopez 1989a, 1989b), which demonstrated that net carbon gain on coarse-grained sediment is at least equal to, and often greater than, that on finegrained sediment. Calculations of net carbon intake and snail growth, combined with estimates of field microalgal concentration and snail density, suggest that population density of Hydrobia truncata at West Meadow Beach is below that at which food limitation is likely to occur (Forbes and Lopez 1989a). 
Table 6. Fecundity Experiment. Results of I-way ANOVA of the effect of sediment type on the number of eggs laid and the percent hatch for snails from Flax Pond, Setauket Harbor, and West Meadow Beach populations. Homogeneity of variances was tested using Bartlett's Test; $P>0.05$.

\begin{tabular}{|c|c|c|c|c|c|}
\hline \multicolumn{6}{|c|}{ I. Flax Pond } \\
\hline Error & 57788.33 & 66 & 2626.74 & & \\
\hline \multicolumn{6}{|c|}{ Dependent Variable: Percent Hatch } \\
\hline \multicolumn{6}{|c|}{ II. Setauket Harbor } \\
\hline \multicolumn{6}{|c|}{ Dependent Variable: Eggs } \\
\hline Sediment & 21540.04 & 1 & 21540.04 & 5.24 & 0.032 \\
\hline Error & 90366.92 & 22 & 4107.59 & & \\
\hline \multicolumn{6}{|c|}{ III.West Meadow Beach } \\
\hline \multicolumn{6}{|c|}{ Dependent Variable: Eggs } \\
\hline Sediment & 37052.04 & I & 37052.04 & 32.21 & $<0.001$ \\
\hline Error & 25303.58 & 22 & 1150.16 & & \\
\hline \multicolumn{6}{|c|}{ Dependent Variable: Percent Hatch } \\
\hline Sediment & 858.01 & 1 & 858.01 & 2.52 & 0.127 \\
\hline Error & 7506.40 & 22 & 341.20 & & \\
\hline
\end{tabular}

Due to the small size of this species, it was impractical to mark and recapture individuals to estimate growth rates. Growth rate comparisons among populations using mean size will be biased if the degree of size-dependent mortality or migration vary among habitats. Casual inspection indicated that the abundance of crabs, shore-birds and juvenile fish, likely predators of Hydrobia species (Fish and Fish 1974; Hylleberg 1986), is highest in the muddy salt-marsh habitat. Predation therefore does not appear a likely explanation for the small sizes and low densities observed at West Meadow Beach. Size-dependent mortality or removal may result from factors other than predation (i.e., due to transport by water currents) and may contribute to size differences among populations.

Sediment grade may influence the time available for feeding in intertidal habitats due to its effect on sediment porosity and drainage. H. truncata will feed when exposed to air, but as the sediment loses moisture the snails will eventually retreat into their shells (Forbes 1988). The greater porosity of sandy sediments may result in decreased feeding activity, compared to muddy habitats, during low tide. Thus the West Meadow Beach population may have had a lower average foraging time relative to the other populations. The smaller size of snails from Setauket Harbor ( $2 \%$ silt-clay) compared to those from Flax Pond (12\% silt-clay) might also be related to differences in sediment water content at low tide.

Sediment grade in aquatic habitats is generally a function of the degree of water flow. Muddy sediments tend to accumulate in quiescent areas, whereas sandy sediments are often indicative of energetic conditions (Eltringham 1971). Sed- iment transport events are common at West Meadow Beach, and such disturbance may have negative effects on survival and available foraging time for snails in this habitat. If wave energy, and not sediment grade, primarily controls size and abundance of $H$. truncata, then large and dense populations of Hydrobia species should occur in sandy but quiescent habitats. Such populations have been observed around Cape Cod, Massachusetts where a lack of availability of fine sedimentary material results in an abundance of low-energy habitats having sediment grades and sedimentary chlorophyll- $\alpha$ values similar to those at West Meadow Beach (D. Carey pers. comm.; V. Forbes unpublished).

In conclusion, the larger body sizes and population densities of $H$. truncata occupying muddy habitats can not be attributed to faster growth afforded by greater food availability on fine-grained sediment. Differences in body size due to variability in the timing of recruitment may be augmented by environmental constraints on growth. The resulting differences in population dynamics among conspecifics from different habitats may be of particular importance in annual, semelparous species.

Acknowledgments - We thank D. Carey, R. Cerrato, R. Etter, T. Forbes, J. Levinton, A. Okubo, C. Peterson, and R. Whitlatch for helpful discussions and critical review of various drafts of this manuscript. G. Davis identified the snail populations and was invaluable for his knowledge of hydrobiid morphology and systematics. T. Forbes provided assistance in the field. Funding was provided by NSF grant OCE8501140 to G. Lopez. 


\section{References}

Bianchi TS, Levinton JS (1984) The importance of microalgae, bacteria and particulate organic matter in the somatic growth of Hydrobia totteni. J Mar Res 42: 431-443

Cammen LM (1982) Effect of particle size on organic content and microbial abundance within four marine sediments. Mar Ecol Prog Ser 9:273-280

Chatfield JE (1972) Studies on variation and life history in the prosobranch Hydrobia ulvae. J Conch 27:463-473

Deflaun MF, Mayer LM (1983) Relationships between bacteria and grain surfaces in intertidal sediments. Limnol Oceanogr 28:873-881

Eltringham SK (1971) Life in mud and sand. The English Universities Press, Ltd., London, p 218

Fenchel T, Kofoed LH (1976) Evidence for exploitative interspecific competition in mud snails (Hydrobiidae). Oikos 27:367-376

Fenchel T, Kofoed LH, Lappalainen A (1975) Particle size-selection of two deposit feeders: The amphipod Corophiumv olutator and the prosobranch Hydrobia ulvae. Mar Biol $30: 119-128$

Fish JD, Fish S (1974) The breeding cycle and growth of Hydrobia ulvae in the Dovey Estuary. J Mar Biol Ass UK 54:685-697

Forbes VE (1988) Intraspecific variation among populations of the deposit-feeding gastropod, Hydrobia truncata: The effect of sediment particle size on physiological energetics. PhD dissertation, State University of New York, Stony Brook, New York

Forbes VE, Lopez GR (1989a) The role of sediment particle size in the nutritional energetics of a surface deposit feeder. I. Ingestion and absorption of sedimentary microalgae by Hydrobia truncata (Vanatta). J Exp Mar Biol Ecol 126:181-192

Forbes VE, Lopez GR (1989b) The role of sediment particle size in the nutritional energetics of a surface deposit feeder. II. Metabolic cost estimated as ${ }^{14} \mathrm{C}$-loss from uniformlylabeled Hydrobia truncata (Vanatta). J Exp Mar Biol Ecol 126:193-202

Hylleberg J (1986) Distribution of hydrobiid snails in relation to salinity, with emphasis on shell size and co-existence of the species. Ophelia 4:85-100

Jensen KT, Siegismund HR (1980) The importance of diatoms and bacteria in the diet of Hydrobia-species. Ophelia 1:193-199

Kaufmann KW (1981) Fitting and using growth curves. Oecologia 49:293-299

Kofoed LH (1975) The feeding biology of Hydrobia ventrosa (Montagu). I. The assimilation of different components of the food. J Exp Mar Biol Ecol 19:233-241

Levinton JS (1972) Stability and trophic structure in depositfeeding and suspension-feeding communities. Am Nat 106:472-486

Levinton JS (1977) The ecology of deposit-feeding communities: Quisset Harbor, Massachusetts. In: Coull BC, ed., Ecology of marine benthos. University of South Carolina Press, Columbia, South Carolina, pp 191-228

Levinton JS (1982) The body size-prey size hypothesis: The adequacy of body size as a vehicle for character displacement. Ecology 63:869-872
Levinton JS (1985) Complex interactions of a deposit feeder with its resources: Roles of density, a competitor, and detrital addition in the growth and survival of the mudsnail Hydrobia totteni. Mar Ecol Prog Ser 22:31-40

Levinton JS, Bianchi TS (1981) Nutrition and food limitation of deposit-feeders. I. The role of microbes in the growth of mud snails (Hydrobiidae). J Mar Res 39:531-545

Longbottom MR (1970) The distribution of Arenicola marina (L.) with particular reference to the effects of particle size and organic matter of the sediments. J Exp Mar Biol Ecol 5:138-157

Lopez GR, Kofoed LH (1980) Epipsammic browsing and deposit-feeding in mud snails (Hydrobiidae). J Mar Res 38:585-599

Lopez GR, Levinton JS (1978) The availability of microorganisms attached to sediment particles as food for Hydrobia ventrosa Montagu (Gastropoda: Prosobranchia). Oecologia 32:263-275

Lopez GR, Levinton JS (1987) Ecology of deposit-feeding animals in marine sediments. Quart Rev Biol 62:235-260

Mayer LM, Rahaim PT, Guerin W, Macko SA, Watling L, Anderson FE (1985) Biological and granulometric controls on sedimentary organic matter of an intertidal mudflat. Est Coast Shelf Sci 20:491-503

Morrisey DJ (1987) Effect of population density and presence of a potential competitor on the growth rate of the mud snail Hydrobia ulvae (Pennant). J Exp Mar Biol Ecol 108:275-295

Morrisey DJ (1988) Differences in effects of grazing by depositfeeders Hydrobia ulvae (Pennant) (Gastropoda: Prosobranchia) and Corophiuma renarium Crawford (Amphipoda) on sediment microalgal populations. II. Quantitative effects. J Exp Biol Ecol 118:43-53

Newell RC (1965) The role of detritus in the nutrition of two marine deposit feeders, the prosobranch Hydrobia ulvae and the bivalve Macoma balthica. Proc Zool Soc Lond 144:25-45

Olafsson EB (1986) Density dependence in suspension-feeding and deposit-feeding populations of the bivalve Macoma balthica: A field experiment. J Anim Ecol 55:517-526

Sanders HL (1958) Benthic studies in Buzzards Bay. I. Animalsediment relationships. Limnol Oceanogr 3:245-258

Sokal RR, Rohlf FJ (1981) Biometry, second edition. W.H. Freeman and Company, San Francisco, California, p 859

Strickland JDH, Parsons TR (1972) A practical handbook of sea-water analysis. Fish Res Bd Can Bull 167, 2nd ed., p 310

Whitlatch RB, Weinberg JR (1982) Factors influencing particle selection and feeding rate in the polychaete Cistenides (Pectinaria) gouldii. Mar Biol 71:33-40

Wilkinson L (1986) SYSTAT. SYSTAT, Inc., Evanston, Illinois

Yamamoto N, Lopez GR (1985) Bacterial abundance in relation to surface area and organic content of marine sediments. J Exp Mar Biol Ecol 90:209-220

Zobell CE (1938) Studies on the bacterial flora of marine bottom sediments. J Sed Petrol 8:10-18 